\title{
1 Influence of the ecological opportunity of interaction on the structure
}

\section{of host-parasite networks}

3 Elvira D’Bastiani ${ }^{1 *}$, Karla Magalhães Campião², Walter Antonio Boeger ${ }^{2}$, Sabrina Borges Lino

\section{Araújo $^{3}$}

51 Programa de Pós-Graduação em Ecologia e Conservação, Laboratório de Interações Biológicas - Setor

6 de Ciências Biológicas, Caixa Postal 19031, CEP 81531-990, Curitiba, PR, Brasil.

7 2Departamento de Zoologia, Laboratório de Interações Biológicas - Setor de Ciências Biológicas, Caixa

8 Postal 19031, CEP 81531-990, Curitiba, PR, Brasil.

93 Departamento de Física, Laboratório de Interações Biológicas - Setor de Ciências Biológicas, Caixa 10 Postal 19031, CEP 81531-990, Curitiba, PR, Brasil.

11 *Corresponding author: Elvira D'Bastiani, Programa de Pós-Graduação em Ecologia e Conservação, 12 Laboratório de Interações Biológicas - Setor de Ciências Biológicas, Universidade Federal do Paraná, 


\section{Abstract}

31 Despite the great interest to quantify the structure of ecological networks, the influence of morphological, ecological and evolutionary characteristics of the species still remains poorly understood. One of the challenging issues in ecology is how the interaction opportunity influences and provides changes to the associations between species, and which effects these changes have on ecological systems. To explore topological patterns in host-parasite networks, we sampled endoparasites-anurans interactions in South America in order to determine whether the effect of the ecological opportunity affects our understanding of the topological structure of the interaction networks. To identify the effect of the ecological opportunity for interaction, we investigated interactions in environments with and without flood pulse, where presence would promote higher ecological opportunity of interaction. Moreover, we created three theoretical models with filters to test the influence of the ecological opportunity for interaction: random, phylogeny and host body size. We then calculated commonly used binary network metrics (connectance, nestedness and modularity) for the networks generated by the theoretical models. We demonstrated that the interaction ecological opportunity changes the structure of host-parasite networks, and was influenced mainly by phylogeny and body size of the host. Our results indicate that environments that offer greater opportunities for interaction between species present networks with the most connectance/nestedness and less modularity. Networks in environments that do not have such opportunities for interaction depict the opposite pattern. Our results indicate that the ecological opportunity of interaction is reflected in an increase in interaction associations between species and affect/change the organization of these interactive assemblages. From an epidemiological point of view, changes in the composition of parasitic species are associated with risks of invasions and emerging diseases. In part, emerging diseases are the result of processes such as those occurring during the flood pulse, in which climate change, travel, and global trade create opportunities for new species associations. Our results provide insight into the dynamics of incorporating a new resource, considering an evolutionary factor responsible for these changes in species composition. 


\section{Introduction}

60 Understanding factors that determine the establishment and persistence of interactions

61 between species is fundamental to comprehend the factors that structure ecological

62 communities [40]. Host-parasite interactions are influenced by characteristics of the

63 hosts and associated parasites. For hosts, characteristics such as body size and

64 structure, diet, age, and immune system are considered significant $[43,48,23]$, but these

65 and others are the resources that dictate the feasibility of the association with specific

66 parasite species [7, 15]. Important characteristics on the parasite species include life

67 cycle complexity [23], virulence, transmissibility, strategies to evade immune responses

68 [65], host species recognition, and trophic requirements [45], among others. Therefore,

69 the effects of these features directly influence the structure of interaction networks.

Hence, intrinsic factors/characteristics of each association determine the potential

71 for an interaction to occur, and compose what Combes [21], Araujo et al. [7], and [15]

72 designate as compatibility. However, the effective establishment of a compatible

73 interaction depends on the encounter opportunity $[7,15,73]$. This effectiveness is often

74 the result of ecological adaptation [38], which postulates that key characteristics shared

75 with previous host species are necessary for a successful infection $[33,12,74]$. The

76 ecological adaptation is the process that allows the parasite organism to successfully

77 colonize a new host without the need of evolutionary novelties [3,50].

78 The support to this new vision of parasitism lies in the fact that the

79 macroevolutionary process, commonly named host-switching, has proven to be much

80 more common in nature than previously thought $[74,15]$. Many human pathogens

81 originate through host-switching, including HIV and malaria [76], and host-shifts are also

82 the predominant cause of new host-parasite associations for rabies viruses in bats [70],

83 malaria in birds [28], and among other associated diseases [14, 50, 55,59]. 
The ecological opportunity for interaction is significantly influenced by the

85 environment [15]. Cyclical changes in expansion and isolation, for instance, generate

86 Taxon Pulse processes [27, see also 34]. Taking this into account, Taxon Pulse

87 processes can lead to increase or limitation of opportunities for interaction between

88 hosts and parasites and, consequently, alter the structure of the community. The flood

89 pulse, for example, is considered a key factor in the ecological functioning and the

90 patterns of lowland communities [63,71]. These flood pulses [41] tend to reduce spatial

91 variability and biological as well as environmental factors [9,71]. According to this

92 hypothesis, during low water periods, floodplains are more isolated from each other and

93 disconnected from the main channel of the river, creating isolated habitats, often with

94 distinct environmental characteristics. On the other hand, subsequent increases in water

95 levels represent an expansion event for aquatic and semiaquatic organisms. We

96 postulate that this pattern of isolation/expansion between neighboring aquatic habitats

97 (flood plain/flood pulse system) provides the ecological opportunity for encounter

98 between endoparasites and anurans species, which may result in new interactions

99 through ecological adjustment. By contrast, continuously isolated habitats provide more

100 limited opportunities for encounter between hosts and parasitic species. In fact, some

101 studies have reported greater similarity between species in the composition of different

102 aquatic habitats during floods than during non-flood periods [5,9,63,72]. We also expect

103 that the structure of communities subjected to cycles/pulses of isolation and expansion

104 will present greater sharing and connectivity of endoparasites between hosts. Limited

105 ecological opportunity in continuously isolated habitats should exhibit less parasite 106 sharing and lower endoparasites connectivity among the anuran hosts, changing the 107 structure of the network. 
bioRxiv preprint doi: https://doi.org/10.1101/2020.01.13.904151; this version posted January 13, 2020. The copyright holder for this preprint (which was not certified by peer review) is the author/funder, who has granted bioRxiv a license to display the preprint in perpetuity. It is made available under aCC-BY 4.0 International license.

In this study, we tested whether this structure is influenced by phylogeny and body

109 size hosts and whether the periodic ecological opportunity of encounters influences the

110 structure of an anuran-endoparasite (endoparasite-anuran) interaction network in

111 environments with and without annual flood pulses. We used a database of anuran-

112 endoparasite interactions to infer how the network structure of each environment can be

113 explained by randomly sampled networks obtained under different theoretical models

114 with filters: neutral, host phylogeny, and host body size. If phylogeny or body size

115 imposes restrictions on species interactions, we expect to find compartments in the

116 random networks. On the other hand, if there are no restrictions, networks would show

117 nested patterns with interaction indirectly reflecting the abundance of species. We

118 conclude that, among the filters analyzed, host body size and phylogeny greatly explain

119 the observed host-endoparasite networks. However, similar networks of environments

120 with cyclic flood pulse were not well explained by these filters, strongly suggesting that

121 the increased opportunities provided by the environment can intensify encounters and

122 promote and increase connectivity in the host-parasite local network.

\section{Materials and Methods}

125 To test for differences in ecological opportunity, we selected four parasite-host

126 interaction networks compiled from literature data and described them using network

127 metrics (nestedness, connectance, and modularity). Next, we sought to know if it was

128 possible to explain their structure based on the phylogenetic characteristics and body

129 size of the hosts analyzed. For this, we created theoretical models with filters (see

130 below) and then compared the structure of the four networks analyzed with the networks

131 generated by theoretical models to test the effect of the process of interaction of

132 opportunity in different environments. See the methods for details. 


\section{Host-parasite database}

135 We created a database with reports on the association of interactions between anurans

136 and helminth parasites (endoparasite) from South America. All possible combinations

137 (e.g. amphibians, endoparasites, helminth, anura) were used to search for anuran-

138 endoparasite (endoparasites belonging to the phylum Acanthocephala, Nematoda, and

139 Platyhelminthes, associated with amphibians of the order Anura) empirical studies

140 conducted in South America from 01-Jan-1925 to 20-Dez-2017. These data were

141 collected using online database platforms such as BioOne, Isi JSTOR, PubMed,

142 SciELO, Scopus, and Web of Science. We have updated the amphibian's nomenclature

143 according to the American Museum of Natural History [29]. Leptodactylus latrans

144 interaction reports were not included in the analyses due to many changes in

145 nomenclature. From here on we will call "host" for anuran and "parasite" for helminth

146 parasites. We then generated a binary matrix with these real interactions in which the

147 rows represented host species and the columns represented parasite species. This

148 matrix was used as an interaction database to generate random networks through the

149 theoretical models (filters). We collected 157 peer-reviewed articles and recorded 686

150 real interactions between 215 species of parasites and 170 species of hosts (Appendix

151 S1).

\section{Selection of analyzed environments}

154 During the bibliographical review, four (4) community studies of host-parasite

155 interactions (observed networks) were selected: (i) two studies of flood pulse

156 environments (with annual cycles of water expansion and retraction), which could

157 promote environmental homogenization and higher ecological opportunity for host- 
158 switching: Pantanal - Campião et al. [18], and Chaco - González and Inés [30] flood

159 pulse. The Pantanal network was composed by 11 hosts and 16 parasites (Appendix

160 S2) while the Chaco, by 35 and 46, respectively (Appendix S2) [18,30]. (ii) Two studies

161 from environments without flood pulse, which potentially promote less ecological

162 opportunity for host-switching: Atlantic Rainforest Graça et. [31], and Amazonian forest

163 Bursey et al. [16]. The Atlantic Rainforest network was composed by 11 host and 15

164 parasites (Appendix S2), while the Amazonian forest by 43 and 16 respectively

165 (Appendix S2) [31,16].

166

\section{Theoretical models}

168 To answer our questions, we chose to test the effect of random, phylogeny, and host

169 body size to see the changing structure (ecological opportunity) of host-parasite

170 networks in different environments. We chose phylogeny because it was revealed as a

171 potential driver of parasitic diversity. Host species vary in their evolutionary time of

172 exposure for parasites acquisition and sharing, therefore, suffering variable co-

173 evolutionary constraints [32] which would influence the interactions and the structure of

174 their networks' interaction. We also chose the host body size as it was a good predictor

175 of the diversity of parasite species [17,42,53]. Large hosts can provide more space and

176 resources, and possibly a greater breadth of niches for parasites. Moreover, larger hosts

177 live longer and represent fewer ephemeral habitats than small species and are therefore

178 also more exposed to parasites [61].

179 Three theoretical models with filters were created (random, phylogeny and body

180 size of hosts models - Appendix S3), to test the influence of the ecological opportunity

181 on the structure of host-parasite networks. Each model is characterized as a specific

182 filter that randomly selects hosts and their parasites from the interaction database that 
bioRxiv preprint doi: https://doi.org/10.1101/2020 01.13.904151; this version posted January 13, 2020. The copyright holder for this preprint (which was not certified by peer review) is the author/funder, who has granted bioRxiv a license to display the preprint in perpetuity. It is made available under aCC-BY 4.0 International license.

183 resulted in random networks. Unlike what is commonly used to analyze the structure of

184 networks, our random networks considered only real interactions extracted from the

185 interaction database (collected from the literature). Our models have generated random

186 networks using real interactions and may give a more accurate answer about the

187 topology of the interaction network than other simpler null models commonly used that

188 consider only random interaction simulations, or that weigh only by the interaction ratio

189 of the species network for example. Given this approach the following theoretical models

190 were proposed: i. Neutral Model: No other filter besides the number of host species,

191 being the same number in each observed network (11 hosts for Pantanal, 35 for Chaco,

19211 for Atlantic Rainforest and 43 for Amazonian forest respectively - Appendix S3 - Filter

193 i); ii. Phylogeny Model: This model randomly samples from the database the same

194 number of host species belonging to the same families in the same proportion of the

195 original network, as reported in each observed network (Appendix S3 - Filter ii; Appendix

196 S4 - families of the species by observed network); iii. Body Size Model: This model

197 randomly samples from the database the same number of hosts species with the same

198 body size distribution (considering a standard error of $\pm 5 \%$ ) as reported for hosts species

199 in each observed network (Appendix S3 - Filter iii; Appendix S4 - body size of the

200 species by observed network).

201 For each one of the four environments analyzed, the random networks maintained

202 the number of host species of each observed network (Pantanal, Chaco, Atlantic

203 Rainforest and Amazonian forest). In this way, the number of hosts remained constant

204 (according to each environment), while the number of parasites varied between the

205 random networks, according to the association in the database of recorded interaction.

206 We sampled 1.000 random networks for each model in each environment (random

207 networks per model in Appendix S5). Each random sample was always included in the 
bioRxiv preprint doi: https://doi.org/10.1101/2020 01.13.904151; this version posted January 13,2020 . The copyright holder for this preprint (which was not certified by peer review) is the author/funder, who has granted bioRxiv a license to display the preprint in perpetuity. It is made available under aCC-BY 4.0 International license.

208 interactions database after each randomization, so that a species could be included in 209 more than one random network. We then compared how well the filters explain the 210 observed network (the comparison methods are detailed below). Unfortunately, it was

211 not possible to impose on a similar real filter the ecological opportunity to evaluate the

212 effect of interaction opportunity because we have no observation that refers to such a

213 factor. Aquatic and terrestrial systems have different physical and chemical conditions,

214 which seem to influence the biology and diversity of the organisms living in each of these

215 habitats [75], that is why we assumed phylogenetic conservatism of the organisms living

216 in each of these analyzed habitats. Given their aspects, we hypothesized that flood

217 pulse environments are not as well explained by the filters (neutral, phylogeny, and host

218 body size) as the other environments. We postulate that in environments without flood

219 pulse the phylogenetic conservatism could be higher, that is, as it is an environment with

220 few opportunities the species maintain their interactions over evolutionary time. If this is

221 true, we expect that the networks will be better described by the phylogeny and body

222 size models that are supposed to have their most preserved interactions. This is

223 something we would not observe in the cyclic flood pulse because there is a constant

224 change that interferes with this conservatism.

\section{Data analysis}

\section{Network Metrics}

228 We used the metrics nestedness, connectance, and modularity to characterize the

229 structure of all networks. The nestedness was calculated using the metric proposed by

230 Almeida-Neto et al. [6], to evaluate the presence of interactions that belong to subsets of 231 other interactions. Therefore, a high nestedness value indicates a hierarchy of 232 interactions, in which species that interact with fewer partners (have a lower degree) 
233 interact with a subset of partners from species that have more partners (a higher degree)

234 [8]. Connectance is the proportion of interactions performed for all possible interactions

235 between species in a community [52]. Modularity was calculated using the method

236 proposed by Dormann and Strauß [24], to describe the presence of network groupings,

237 where species interact more with species within their group than with species belonging

238 to other groups [58]. These groups are commonly called network modules, and to

239 calculate these network metrics, we used the commands implemented in the "bipartite"

240 package [25] in $\mathrm{R}[22]$.

\section{Standardization for network metrics}

243 To allow comparison between networks of different sizes, we standardized the network

244 metrics using a simple linear regression between metrics and number of parasites. This

245 standardization is necessary because although the host species richness was constant

246 in the different samples, the size of the whole network differed in each sample due to

247 variation in parasite richness. See below:

$$
\bar{Y}=Y-\alpha^{*} p a r+\beta
$$

where $\bar{Y}$ is the value of the standardized metric (equivalent to the regression

250 residue), $Y$ is the value of the non-standardized metric, par is the number of parasites,

251 and $\alpha$ and $\beta$ are the slope and the linear coefficient of the regression, respectively.

\section{Comparison of the network structure}

254 From here onwards we call "observed network" any of the four observed networks for 255 tested environments, and "random network" any network generated by filters. We 256 identify which model best explains each observed network as well as which network is 257 best described by the models. To compare networks, we first calculated the distance $(D)$ 
258 for each metric, from each random network of each theoretical model to the observed

259 network in units of standard deviation:

$$
D=\left(\bar{Y}_{\text {obs }}-\bar{Y}_{\text {rand }}\right) / \sigma_{\text {rand }}
$$

261 where $\bar{Y}_{\text {obs }}$ is the standardized value of the observed network, $\bar{Y}_{\text {rand }}$ is the

262 normalized value of the random network metric, and $\sigma_{\text {rand }}$ the standard deviation of 1.000

263 values of $\bar{Y}_{\text {rand. }}$ Subsequently, for a given metric and observed network, a unidirectional

264 analysis of variance (ANOVA) was applied to evaluate whether there was a difference

265 between these groups. Tukey's test [79] was used to determine the occurrence of

266 differences between treatments. After measuring the difference, the distance averages

267 between the real networks and each random network of each model was compared to

268 verify which theoretical model best described the observed networks. When the metric

269 and the observed network were fixed, we compared which model best explained the

270 observed network. When the metrics and model were fixed, we compared which

271 observed network was best explained by the models. All statistical analyses were

272 performed using the "stats" package in the R software [22]. For all tests, we assumed

273 the significance of $p<0.05$.

\section{Results}

\section{Structure of host-parasite interaction networks}

277 Some of the random networks presented a range from smaller to greater number of

278 parasite species than the observed networks (Fig. 1, 2, 3 - black bars, upper $\mathrm{x}$ axis -

279 frequency of the number of parasites), except for the Amazon, whose smallest random

280 network had at least twice more parasites than the observed network. Thus, by

281 correcting the effect of network size, the theoretical models could not reach a network as

282 small as that analyzed in the Amazon due to low parasitic richness analyzed in this 
bioRxiv preprint doi: $\mathrm{https}$ //doi.org/10.1101/2020 01.13.904151; this version posted January 13, 2020. The copyright holder for this preprint (which was not certified by peer review) is the author/funder, who has granted bioRxiv a license to display the preprint in perpetuity. It is made available under aCC-BY 4.0 International license.

283 environment (Fig. 1, Fig. 2 and Fig. 3 - j to I). Despite our attempt to control the effect of 284 network size by a standardization method, we were unable to ensure that the ratio of the 285 metric and the number of parasites maintained the same linear tendency for such low 286 numbers of parasites for Amazon. Therefore, the Amazonian simulations were removed 287 from subsequent analysis.

288 The nestedness increases with the number of parasites in the network for the 289 remaining three environments (Fig. 1, Appendix S6). Connectance and modularity were 290 negatively correlated with the number of parasites in most simulated models (Fig. 2 and 291 3, Appendix S6), except for the connectance in simulated neutral models for the 292 Pantanal $\left(R^{2}=0.01, p=0.98\right)$ and Atlantic Rainforest, which were not correlated $\left(R^{2}=\right.$ $2930.002, p=0.15)$.

295 Fig. 1 Nestedness values according to the number of parasite species before standardization. The black 296 dots indicate the nestedness value of random networks for three theoretical models. Grey dot - Pantanal 297 (a, b, c), green dot - Chaco (d, e, f), orange dot - Atlantic Forests ( $g, h, i)$ and violet dot - Amazonian forest $298(\mathrm{j}, \mathrm{k}, \mathrm{l})$. The blue lines represent linear regression and the gray shadow represents standard deviation in 299 random networks. The black bars indicate the frequency distribution of the random networks: right y axis 300 nestedness frequency, upper $\mathrm{x}$ axis - frequency of the number of parasites (details: Appendix S10 in 301 Supporting Information).

303 Fig. 2 Connectance values according to the number of parasite species before standardization. The black 304 dots indicate the connectance value of random networks for three theoretical models. Grey dot - Pantanal 305 (a, b, c), green dot - Chaco (d, e, f), orange dot - Atlantic Forests (g, h, i) and violet dot - Amazonian forest $306(\mathrm{j}, \mathrm{k}, \mathrm{l})$. The blue lines represent linear regression and the gray shadow represents standard deviation over 307 the random networks. The black bars indicate the frequency distribution of the random networks: right $y$ 308 axis - connectance frequency, upper $\mathrm{x}$ axis - frequency of the number of parasites (details: Appendix S10 309 in Supporting Information). 
bioRxiv preprint doi: https://doi.org/10.1101/2020.01.13.904151: this version posted January 13,2020 . The copyright holder for this preprint (which was not certified by peer review) is the author/funder, who has granted bioRxiv a license to display the preprint in perpetuity. It is made available under aCC-BY 4.0 International license.

311 Fig. 3 Modularity values according to the number of parasite species before standardization. The black

312 dots indicate the modularity value of random networks for three theoretical models. Grey dot - Pantanal (a,

313 b, c), green dot - Chaco (d, e, f), orange dot - Atlantic Forests ( $g, h, i)$ and violet dot - Amazonian forest (j,

$314 \mathrm{k}, \mathrm{l})$. The blue lines represent linear regression and the gray shadow represents standard deviation over

315 the random networks. The black bars indicate the frequency distribution of the random networks: right $y$

316 axis - modularity frequency, upper $\mathrm{x}$ axis - frequency of the number of parasites (details: Appendix S10 in

317 Supporting Information).

318

319 Host body size and phylogeny models usually better describe the observed network than neutral models

321 The distance (D) between random networks and their respective observed network were 322 significantly different among the models (Table 1). The body size model that better 323 resembled the nestedness pattern was observed in the Pantanal and Chaco, while in the 324 Atlantic Rainforest, it was the phylogeny model. The connectance values in the Atlantic 325 Rainforest were better resembled by the neutral model, while in the Pantanal and Chaco 326 were better resembled by the body size and phylogeny models, respectively. The 327 modularity was better resembled by the phylogeny model in the Pantanal and Chaco 328 networks, while modularity in the Atlantic Rainforest was best explained by the body size 329 model (Table 1). Such results, with the exception for connectance in the Atlantic 330 Rainforest, show that the body size and phylogeny of the hosts resemble better the 331 network structure than neutral model.

333 Table 1. Analysis of variance (statistical significance test $\mathrm{F}_{2-2997}$ ), Tukey Test between neutral models $(\mathrm{N})$, 334 phylogeny $(\mathrm{P})$ and body size (BS) for each metric and environment (observed network).

\begin{tabular}{cccccc}
\hline \multirow{2}{*}{ Metric } & \multirow{2}{*}{ Environment } & ANOVA & \multicolumn{2}{c}{ Tukey HSD } & \multirow{2}{*}{$<\boldsymbol{D}>$} \\
\cline { 3 - 5 } & & $\mathbf{F}_{2-2997}$ & \multicolumn{2}{c}{ Theoretical Model } & \\
\hline \multirow{2}{*}{ Nestedness } & \multirow{2}{*}{ Pantanal } & $9.10^{*}$ & $\mathrm{P}-\mathrm{N}$ & $\mathrm{BS}$ & 5.85 \\
& & & $\mathrm{BS}-\mathrm{N}^{*}$ & $\mathrm{P}$ & 5.94 \\
& & & & $\mathrm{~N}$ & 6.04 \\
\hline
\end{tabular}




\begin{tabular}{|c|c|c|c|c|c|}
\hline & \multirow{3}{*}{ Chaco } & \multirow{3}{*}{$396.70^{*}$} & $P-N^{*}$ & BS & 3.21 \\
\hline & & & $B S-N^{*}$ & $\mathrm{~N}$ & 4.07 \\
\hline & & & $B S-P^{*}$ & $\mathrm{P}$ & 4.43 \\
\hline & \multirow{3}{*}{ Atlantic Rainforest } & \multirow{3}{*}{$31.34^{*}$} & $P-N^{*}$ & $P$ & 1.27 \\
\hline & & & $B S-N^{*}$ & BS & 1.49 \\
\hline & & & $B S-P$ * & $\mathrm{N}$ & 1.62 \\
\hline \multirow{9}{*}{ Connectance } & \multirow{3}{*}{ Pantanal } & \multirow{3}{*}{$2166.00^{*}$} & $P-N^{*}$ & BS & 12.56 \\
\hline & & & $B S-N^{*}$ & $\mathrm{P}$ & 13.58 \\
\hline & & & $B S-P$ * & $\mathrm{N}$ & 15.46 \\
\hline & \multirow{3}{*}{ Chaco } & \multirow{3}{*}{$251.70^{*}$} & $P-N^{*}$ & $P$ & 4.86 \\
\hline & & & $B S-N$ & BS & 5.68 \\
\hline & & & $B S-P$ * & $\mathrm{N}$ & 5.77 \\
\hline & \multirow{3}{*}{ Atlantic Rainforest } & \multirow{3}{*}{$220.60^{*}$} & $P-N^{*}$ & $\mathrm{~N}$ & 3.68 \\
\hline & & & $B S-N^{*}$ & $\mathrm{P}$ & 4.17 \\
\hline & & & $B S-P$ * & BS & 4.62 \\
\hline \multirow{9}{*}{ Modularity } & \multirow{3}{*}{ Pantanal } & \multirow{3}{*}{$166.50^{*}$} & $P-N^{*}$ & $\mathrm{P}$ & -5.15 \\
\hline & & & $B S-N^{*}$ & BS & -5.33 \\
\hline & & & $B S-P$ * & $\mathrm{N}$ & -5.93 \\
\hline & \multirow{3}{*}{ Chaco } & \multirow{3}{*}{$140.50^{*}$} & $\mathrm{P}-\mathrm{N}^{*}$ & $\mathrm{P}$ & -3.70 \\
\hline & & & $B S-N^{*}$ & $S$ & -4.21 \\
\hline & & & $B S-P$ * & $\mathrm{N}$ & -4.43 \\
\hline & \multirow{3}{*}{ Atlantic Rainforest } & \multirow{3}{*}{$59.74^{*}$} & $P-N^{*}$ & BS & -1.34 \\
\hline & & & $B S-N^{*}$ & $\mathrm{P}$ & -1.68 \\
\hline & & & $B S-P$ * & $\mathrm{N}$ & -1.81 \\
\hline
\end{tabular}

The right column of "Theoretical Model" is ordered according to the model that better describes the observed network for a given metric, followed by the average distance $(<D>)$ between the observed network and the random networks. ${ }^{*}=$ significant difference $<0.01$.

337 The theoretical models describe environments without flood pulse better

338 than the flood pulse environments

339 The resemblance of the network metrics from randomly sampled networks to observed

340 networks environments with and without flooding for each metric presented different

341 distances (Table 2). All metrics pointed network structure of the Pantanal as the furthest

342 from the network structure of the theoretical models (statistics for support Table 2),

343 followed by the Chaco and the Atlantic Rainforest. This shows that the environment

344 without flood pulse is better described by the proposed models than the flood pulse

345 environments. All theoretical models pointed that Pantanal network is the most nested, 
bioRxiv preprint doi: $\mathrm{https} / /$ doi.org/10.1101/2020.01.13.904151. this version posted January 13,2020 . The copyright holder for this preprint (which was not certified by peer review) is the author/funder, who has granted bioRxiv a license to display the preprint in perpetuity. It is made available under aCC-BY 4.0 International license.

connected and less modular one followed by Chaco and Atlantic Rainforest (see the

347 statistics for support test for each metric between random networks of the models and

348 observed network - average distance value, $<D>$, in Table 2).

350 Table 2. Analysis of variance (statistical significance test $\mathrm{F}_{2-2997}$ ), Tukey Test between neutral $(\mathrm{N})$,

351 phylogeny $(\mathrm{P})$ and body size (BS) theoretical models, for each metric and environment.

\begin{tabular}{|c|c|c|c|c|c|}
\hline Metric & Model & $\begin{array}{c}\text { ANOVA } \\
\text { F }_{2-2997} \\
\end{array}$ & $\begin{array}{c}\text { Tukey HSD } \\
\text { Environment }\end{array}$ & Environment & $<D>$ \\
\hline \multirow{9}{*}{ Nestedness } & \multirow{3}{*}{$\mathrm{N}$} & \multirow{3}{*}{$4923^{*}$} & Atlantic Rainforest - Chaco* & Pantanal & 6.04 \\
\hline & & & Pantanal - Chaco* & Chaco & 4.07 \\
\hline & & & Pantanal - Atlantic Rainforest * & Atlantic Rainforest & 1.61 \\
\hline & \multirow{3}{*}{$P$} & \multirow{3}{*}{$5704^{*}$} & Atlantic Rainforest - Chaco* & Pantanal & 5.94 \\
\hline & & & Pantanal - Chaco* & Chaco & 4.43 \\
\hline & & & Pantanal - Atlantic Rainforest* & Atlantic Rainforest & 1.26 \\
\hline & \multirow{3}{*}{ BS } & \multirow{3}{*}{$4840^{*}$} & Atlantic Rainforest - Chaco* & Pantanal & 5.85 \\
\hline & & & Pantanal - Chaco* & Chaco & 3.21 \\
\hline & & & Pantanal - Atlantic Rainforest* & Atlantic Rainforest & 1.48 \\
\hline \multirow{8}{*}{ Connectedness } & \multirow{3}{*}{$\mathrm{N}$} & \multirow{3}{*}{$39508^{*}$} & Atlantic Rainforest - Chaco* & Pantanal & 15.46 \\
\hline & & & Pantanal - Chaco* & Chaco & 5.77 \\
\hline & & & Pantanal - Atlantic Rainforest* & Atlantic Rainforest & 3.68 \\
\hline & \multirow{2}{*}{$P$} & \multirow{2}{*}{$27554^{* *}$} & Atlantic Rainforest - Chaco* & Pantanal & $\begin{array}{c}13.58 \\
486\end{array}$ \\
\hline & & & $\begin{array}{l}\text { Pantanal - Chaco } \\
\text { Pantanal - Atlantic Rainforest* }\end{array}$ & Atlantic Rainforest & $\begin{array}{l}4.00 \\
4.17\end{array}$ \\
\hline & \multirow{3}{*}{ BS } & \multirow{3}{*}{$18577^{*}$} & Atlantic Rainforest - Chaco* & Pantanal & 12.56 \\
\hline & & & Pantanal - Chaco* & Chaco & 5.68 \\
\hline & & & Pantanal - Atlantic Rainforest* & Atlantic Rainforest & 4.62 \\
\hline \multirow{9}{*}{ Modularity } & \multirow{3}{*}{$\mathrm{N}$} & \multirow{3}{*}{$39508^{*}$} & Atlantic Rainforest- Chaco* & Pantanal & -5.93 \\
\hline & & & Pantanal - Chaco* & Chaco & -4.53 \\
\hline & & & Pantanal - Atlantic Rainforest* & Atlantic Rainforest & -1.81 \\
\hline & \multirow{3}{*}{$P$} & \multirow{3}{*}{$27554^{*}$} & Atlantic Rainforest - Chaco* & Pantanal & -5.15 \\
\hline & & & Pantanal - Chaco* & Chaco & -3.79 \\
\hline & & & Pantanal - Atlantic Rainforest * & Atlantic Rainforest & -1.68 \\
\hline & \multirow{3}{*}{ BS } & \multirow{3}{*}{$18577^{*}$} & Atlantic Rainforest - Chaco* & Pantanal & -5.33 \\
\hline & & & Pantanal - Chaco* & Chaco & -4.30 \\
\hline & & & Pantanal - Atlantic Rainforest* & Atlantic Rainforest & -1.34 \\
\hline
\end{tabular}

The fourth column is ordered according to the environment with the most distance between the observed network and random networks, followed by the average distance $(<D>)$ between the observed network and the random networks. ${ }^{*}=$ significant difference $<0.01$. 
bioRxiv preprint doi: https://doi.org/10.1101/2020 01.13.904151; this version posted January 13, 2020. The copyright holder for this preprint (which was not certified by peer review) is the author/funder, who has granted bioRxiv a license to display the preprint in perpetuity. It is made available under aCC-BY 4.0 International license.

354 The method we developed to infer how the structure of anuran-endoparasite interaction

355 networks under different conditions of encounter opportunities could be described by

356 theoretical models based on neutral, host phylogeny and host body filters. We found that

357 the theoretical models described the network without flood pulse - i.e low ecological

358 opportunity for interaction (Atlantic Rainforest) - better than the networks with cyclic

359 flood pulse (Pantanal and Chaco). In addition, the networks of the three environments

360 were best described by the theoretical models with phylogeny or host body size filters

361 rather than the neutral filter. This result suggests that, in fact, the increased ecological

362 opportunity for encounters provided by the environment increases connectivity through

363 the incorporation of new host species in the repertoire of the parasites.

364 The topology patterns observed in the communities reflect the mechanisms that

365 structure their respective networks. Some studies suggest randomness as an underlying

366 mechanism for explaining the structure of parasitic communities [44,62]. However, the

367 metrics we tested in our study did not indicate the neutral model as the main structuring

368 mechanism for network topology, except for the connectance of the network in the

369 Atlantic Rainforest. The interactions of the Atlantic Rainforest can be the result of

370 random neutral encounters between individuals, whose probability is mediated by the

371 relative abundances of the populations involved and by compatibility in the case of

372 parasites.

373 In parasitic communities, the evolutionary history of the host acts as one of the

374 determinants of the community structure [19,67]. Phylogenetic relationships function as

375 a good proxy for describing ecological differences between hosts and host groups. This

376 may indicate that these attributes are phylogenetically conserved, modulating

377 interspecific barriers for parasite colonization among hosts [19,36], and outlining current

378 interactions [26,64]. 
bioRxiv preprint doi: https://doi.org/10.1101/2020.01.13.904151; this version posted January 13, 2020. The copyright holder for this preprint (which was not certified by peer review) is the author/funder, who has granted bioRxiv a license to display the preprint in perpetuity. It is made available under aCC-BY 4.0 International license.

Many life-history traits are positively correlated with body size and therefore may

380 have affected the structure and dynamics of ecological networks at multiple scales of

381 biological organization, from the individual to the ecosystem $[20,60,66,77]$. Currently, the

382 major challenge is to develop a body of theory that can explore the implications of body

383 size on the structure and functioning of the host-parasite networks.

384 The metrics of the Atlantic Rainforest networks were more similar to the theoretical

385 models than the Pantanal and Chaco networks (Fig. 1, 2, 3 and Table 2). These points

386 to other potential factor(s), besides phylogeny and size, acting on the structure of the

387 Pantanal and Chaco networks. Unlike the Atlantic Rainforest, the Pantanal and Chaco

388 are environments marked by large annual floods. As we suggested, the presence of

389 these floods promotes greater contact between aquatic and semi-aquatic species, thus

390 increasing the ecological opportunity for the establishment of new host-parasite

391 associations [2,4]. The encounters can lead to new associations by ecological fitting, i.e.

392 the ability of organisms to adapt quickly to new resources due to their phenotypic

393 flexibility, without genetic novelties $[3,7,38]$.

394 Moreover, species may expand habitat use in response to the availability of new

395 resources $[49,78]$, which would be associated with the encounter of different hosts in this

396 study. Some examples of habitat expansion (colonization and adaptation to new

397 resources or other new selective ecological adjustment scenarios) arise directly from the

398 events associated with the ecological opportunity [51]. Cyclical expansion of host399 parasitic communities in the ecosystems subjected to annual flood pulses favors 400 seasonal contact of infectious forms of parasites with hosts. The colonization of new 401 host species should in fact generate more connected, more nested, and less modular 402 networks (since modules are broken due to the new connections promoted by the 403 environment - Fig. 3, a-f). These events increase the repertoire of the parasite, and may 
bioRxiv preprint doi: $h$ ttps://doi.org/10.1101/2020 01.13.904151; this version posted January 13, 2020. The copyright holder for this preprint (which was not certified by peer review) is the author/funder, who has granted bioRxiv a license to display the preprint in perpetuity. It is made available under aCC-BY 4.0 International license.

404 represent the beginning of speciation processes, or, they could maintain its repertoire of 405 host as well as postulated by "Oscillation hypothesis" $[10,37,56]$. This hypothesis 406 consists largely of micro and macroevolutionary aspects. The microevolutionary part 407 deals with how novel hosts are incorporated during host expansions and, as a 408 consequence, pathogenic lineages can diversify in resource use. The second part is 409 largely macroevolutionary and foresees that these episodes of increased host use 410 should lead to elevated rates of diversification. The particularities of the 411 microevolutionary part affect the specific patterns expected at the macroevolutionary 412 level. In this context, over the course of evolutionary time, true generalist species may 413 become specialists, and vice versa $[4,37,56]$. In environments without flood pulse, such as the Atlantic Rainforest, the host415 parasite interaction may be restricted by the low dispersion of species among aquatic 416 environments, since for many semi-aquatic and aquatic species, the forest environments 417 may represent ecological barriers. As contact is the main route of parasite transmission 418 (expected for endoparasites with heteroxenous and monoxenic cycle), the structure of 419 the Atlantic Rainforest network is very similar to the structure of random networks, since 420 hosts share fewer parasites. Our results suggest that the ecological opportunity for 421 interaction may play an important role in determining the structure of interaction 422 networks and the evolutionary dynamics of host-parasite associations. These results 423 create new perspectives for studies on parasitic community assemblages, particularly as 424 few studies relate the connectivity of host communities to the opportunity for parasitic 425 dispersion. This may, in fact, increase our understanding on the influence of the 426 dynamics of the physical environment on the structure of host-parasites interactions.

427 From an epidemiological perspective, changes in the composition of parasitic 428 species or in the frequency of host-parasite interactions are associated with the risks of 
bioRxiv preprint doi: https://doi.org/10.1101/2020 01.13.904151; this version posted January 13, 2020. The copyright holder for this preprint (which was not certified by peer review) is the author/funder, who has granted bioRxiv a license to display the preprint in perpetuity. It is made available under aCC-BY 4.0 International license.

parasitic invasions and emerging diseases [1,4,11,13,33,39,46,54]. Some examples

430 come from studies with the introductions of species [35,57]. In birds, for instance, the

431 occurrence of nematode parasites increases with the ecological opportunity due to

432 migratory habits and the use of aquatic habitat $[47,57]$. This results in a change in

433 community structure and the formation of new species associations through a

434 combination of mechanisms, such as ecological adaptation and opportunity for

435 interaction between species [68,69]. In part, the emerging diseases are a result of

436 processes such as those that occur during the flood pulse, in which climate change,

437 travel, and global trade generate opportunities for new species associations [57]. We

438 show that an insight is provided into the dynamics of the incorporation of a new

439 resource, as an evolutionary factor considered to be responsible for changes in species

440 composition.

441 Our results may have been influenced by the fact that the host-parasites interaction

442 database was built from several studies, with different sampling efforts in different

443 regions. This could have increased the interaction records, and, consequently, increased

444 the connectance and reduced the modularity of theoretical models. On the other hand,

445 the interaction database had a larger spatial scale than the local studies in the analyzed

446 environments, so that the random networks could have selected hosts that did not co-

447 occur and, therefore, did not share the same species of parasites, resulting in more

448 modular, but less connected random networks. Even so, the variation in network size

449 between the simulations is high; there is a risk that methodological artifacts (low sample

450 effort) may have been affected, especially in the Amazon network. The fact that the

451 Amazon has a low parasitic richness could be due to the lower sampling effort.

452 Therefore, we opted for excluding this environment from our analyses. However, even 
453 with these factors, all the observed networks had the same tendency; they were all more

454 connected and less modular than predicted by the models, thus validating our results.

455

\section{Acknowledgements}

457 The authors would like to thank the Academic Publishing Advisory Center (Centro de

458 Assessoria de Publicação Acadêmica, CAPA - www.capa.ufpr.br) of the Federal

459 University of Paraná for assistance with English editing. EDB was supported by a Master

460 degree fellowship from Coordenação de Aperfeiçoamento de Pessoal de Nível Superior

461 (CAPES).

462

\section{Author Contributions}

$464 \mathrm{KMC}, \mathrm{WAB}, \mathrm{SBLA}$ and EDB originally formulated the idea. SBLA and EDB developed the 465 mathematical models, conducted work and generated data analyses. EDB, SBLA, KMC 466 and WAB wrote the manuscript.

467

\section{Conflict of interest}

469 The authors declare that they have no conflict of interests.

\section{References}

1. Adlard RD, Miller TL, Smit NJ. The butterfly effect: parasite diversity, environment, and emerging disease in aquatic wildlife. Trends in Parasitology. 2015;31(4):160-166.

2. Agosta SJ. On ecological fitting, plant-insect associations, herbivore host shifts, and host plant selection. Oikos. 2006;114(3):556-565. 
3. Agosta SJ, Klemens JA. Ecological fitting by phenotypically flexible genotypes: implications for species associations, community assembly and evolution. Ecology Letters. 2008;11(11):1123-1134.

4. Agosta SJ, Janz N, Brooks DR. How specialists can be generalists: resolving the "parasite paradox" and implications for emerging infectious disease. Zoologia. 2010;27(2):151-162.

5. Agostinho AA, Thomaz SM, Minte-Vera CV, Winemiller KO. Biodiversity in the high Paraná river Floodplain. In. Gopal B, Junk WJ, Davis JA. Biodiversity in wetlands: assessment, function and conservation, Backhuys Publishers, Leiden; 2000. p. 89-118.

6. Almeida-Neto M, Guimaraes P, Guimaraes Jr PR, Loyola RD, Ulrich W. A consistent metric for nestedness analysis in ecological systems: reconciling concept and measurement. Oikos. 2008;117(8):1227-1239.

7. Araujo SB, Braga MP, Brooks DR, Agosta SJ, Hoberg EP, von Hartenthal FW, et al. Understanding host-switching by ecological fitting. Plos One. 2015;10(10):e0139225.

8. Bascompte J, Jordano, P, Melián CJ, Olesen JM. The nested assembly of plantanimal mutualistic networks. Proceedings of the National Academy of Sciences. 2003;100(16):9383-9387.

9. Bozelli RL. Composition of the zooplankton community of Batata and Mussura lakes and the Trombetas River, State of Pará, Brazil. Amazoniana. 1992;12:239261.

10.Braga MP, Araujo SB, Agosta S, Brooks D, Hoberg E, Nylin S, et al. Host use dynamics in a heterogeneous fitness landscape generates oscillations in host range and diversification. Evolution. 2018;72(9):1773-1783. 
11.Brooks DR, Hoberg EP. How will global climate change affect parasite-host assemblages? Trends in parasitology. 2007;23(12):571-574.

12. Brooks DR, León-Règagnon V, McLennan DA, Zelmer D. Ecological fitting as a determinant of the community structure of platyhelminth parasites of anurans. Ecology. 2006;87(sp7):S76-S85.

13. Brooks DR, Hoberg EP, Boeger WA, Gardner SL, Galbreath K, Herczeg D, et al. Finding them before they find us: informatics, parasites, and environments in accelerating climate change. Comparative Parasitology. 2014;81(2):155-165.

14. Brooks DR, Hoberg EP, Boeger WA. In the eye of the cyclops: the classic case of cospeciation and why paradigms are important. Comparative Parasitology. 2015;82(1):1-9.

15. Brooks DR, Hoberg EP, Boeger WA. The Stockholm paradigm: Climate change and emerging disease. 4th ed. University of Chicago Press, 2019.

16. Bursey CR, Goldberg SR, Parmelee JR. Gastrointestinal helminths of 51 species of anurans from Reserva Cuzco Amazónico, Peru. Comparative Parasitology. 2001;68(1):21-35.

17. Campiao KM, de Aquino Ribas AC, Morais DH, da Silva RJ, Tavares LER. How many parasites species a frog might have? Determinants of parasite diversity in South American anurans. Plos One. 2015;10(10):e0140577.

18. Campião KM, da Silva ICO, Dalazen GT, Paiva F, Tavares LER. Helminth parasites of 11 anuran species from the Pantanal Wetland, Brazil. Comparative parasitology. 2016;83(1):92-101.

19. Clark NJ, Clegg SM, Sam K, Goulding W, Koane B, Wells K. Climate, host phylogeny and the connectivity of host communities govern regional parasite assembly. Diversity and Distributions. 2018;24(1):13-23. 
20. Cohen JE, Jonsson T, Müller CB, Godfray HCJ, Savage VM. Body sizes of hosts and parasitoids in individual feeding relationships. Proceedings of the National Academy of Sciences. 2005;102(3):684-689.

21. Combes C. Parasitism: the ecology and evolution of intimate interactions. University of Chicago Press, London. 2001.

22. Core Team. R: A language and environment for statistical computing. $R$ Foundation for Statistical Computing, Vienna, Austria ISBN 3-900051-07-0, URL http://www.R-project.org/.2018.

23. Dallas T, Hall RJ, Drake JM. Competition-mediated feedbacks in experimental multispecies epizootics. Ecology. 2016;97(3):661-670.

24. Dormann CF, Strauss R. A method for detecting modules in quantitative bipartite networks. Methods in Ecology and Evolution. 2014;5(1):90-98.

25.Dormann CF, Gruber B, Fründ J. Introducing the bipartite package: analysing ecological networks. Interaction. 2008;1:0.2413793.

26. Dormann CF, Von Riedmatten L, Scherer-Lorenzen M. No consistent effect of plant species richness on resistance to simulated climate change for above-or below-ground processes in managed grasslands. BMC Ecology. 2017;17(1):23.

27. Erwin TL. The taxon pulse: a general pattern of lineage radiation and extinction among carabid beetles. Taxonomy, phylogeny, and zoogeography of beetles and ants. 1985;437-472.

28. Fecchio A, Pinheiro R, Felix G, Faria IP, Pinho JB, Lacorte GA, et al. Host community similarity and geography shape the diversity and distribution of haemosporidian parasites in Amazonian birds. Ecography. 2018;41(3):505-515. 
30. González CE and Hamann MI. Checklist of nematode parasites of amphibians from Argentina. Zootaxa. 2015;3980(4):451-76.

31. Graça RJ, Oda FH, Lima FS, Guerra V, Gambale PG, Takemoto RM. Metazoan endoparasites of 18 anuran species from the mesophytic semideciduous Atlantic Forest in southern Brazil. Journal of Natural History. 2017;51(13-14):705-729.

32. Hadfield JD, Krasnov BR, Poulin R, Nakagawa S. A tale of two phylogenies: comparative analyses of ecological interactions. The American Naturalist. 2013;183(2):174-187.

33. Hoberg EP and Brooks DR. A macroevolutionary mosaic: episodic hostswitching, geographical colonization and diversification in complex host-parasite systems. Journal of Biogeography. 2008;35(9):1533-1550.

34. Hoberg EP, Brooks DR. Beyond vicariance: integrating taxon pulses, ecological fitting, and oscillation in evolution and historical biogeography. The biogeography of host-parasite interactions. In Morand S, Krasnov BR (eds.) The biogeography of host-parasite interactions. Oxford University Press, 2010. p. $7: 20$.

35. Hoberg EP and Zarlenga DS. Evolution and biogeography of Haemonchus contortus: linking faunal dynamics in space and time. In: Gasser RB and Von Samson, Advances in Parasitology. Haemonchus contortus and Haemonchosis - Past, Present and Future Trends. 2016. P. 1-30. Phylogenetically related and ecologically similar carnivores harbour similar parasite assemblages. Journal of Animal Ecology. 2014;83(3):671-680. 
37. Janz N, Nylin S, Wahlberg N. Diversity begets diversity: host expansions and the diversification of plant-feeding insects. BMC evolutionary biology. 2006;6(1):4

38. Janzen DH. On ecological fitting. Oikos. 1985;45:308-310.

39. Jones KE, Patel NG, Levy MA, Storeygard A, Balk D, Gittleman JL, et al. Global trends in emerging infectious diseases. Nature. 2008;451(7181):990993Kaiser.

40. Joppa LN and Williams R. Modeling the building blocks of biodiversity. Plos One. 2013;8(2):e56277.

41. Junk WJ, Bayley PB, Sparks RE. The flood pulse concept in river-floodplain systems. Canadian special publication of fisheries and aquatic sciences. 1989;106(1):110-127.

42. Kamiya T, O'Dwyer K, Nakagawa S, Poulin R. What determines species richness of parasitic organisms? A meta-analysis across animal, plant and fungal hosts. Biological Reviews. 2014;89(1):123-134.

43. Krasnov BR, Fortuna MA, Mouillot D, Khokhlova IS, Shenbrot GI, Poulin R. Phylogenetic signal in module composition and species connectivity in compartmentalized host-parasite networks. The American Naturalist. 2012;179(4):501-511.

44. Krishna A, Guimaraes Jr PR. Jordano P, Bascompte J. A neutral-niche theory of nestedness in mutualistic networks. Oikos. 2008;117(11):1609-1618.

45. Lafferty KD, Kuris AM. Trophic strategies, animal diversity and body size. Trends in Ecology \& Evolution. 2002;17(11):507-513. 2009;90(4):888-900. 
47. Leung TLF and Koprivnikar J. Nematode parasite diversity in birds: the role of host ecology, life history and migration. Journal of Animal Ecology. 2016;85(6):1471-1480.

48. Locke SA, McLaughlin JD, Marcogliese DJ. Predicting the similarity of parasite communities in freshwater fishes using the phylogeny, ecology and proximity of hosts. Oikos. 2013;122(1):73-83.

605

49. MacArthur RH, Diamond JM, Karr JR. Density compensation in island faunas.

606 Ecology. 1972;53(2):330-342.

50. Mácová A, Hoblíková A, Hypša V, Stanko M, Martinů J, Kvičerová J. Mysteries of host switching: Diversification and host specificity in rodent-coccidia associations. Molecular phylogenetics and evolution. 2018;127:179-189.

51. Malcicka M, Agosta SJ, Harvey JA. Multi level ecological fitting: indirect life cycles are not a barrier to host switching and invasion. Global change biology 2015;21(9):3210-3218.

52. May RM. Stability and complexity in model ecosystems. Princeton University Press. v. 6. 1974.

53. Morand S. (Macro-) Evolutionary ecology of parasite diversity: From determinants of parasite species richness to host diversification. International Journal for Parasitology: Parasites and Wildlife. 2015;4(1):80-87.

54. Morse SS, Mazet JA, Woolhouse M, Parrish CR, Carroll D, Karesh WB, et al. Prediction and prevention of the next pandemic zoonosis. The Lancet. 2012;380(9857):1956-1965.

55. Navaud O, Barbacci A, Taylor A, Clarkson JP, Raffaele S. Shifts in diversification rates and host jump frequencies shaped the diversity of host 
range among Sclerotiniaceae fungal plant pathogens. Molecular ecology. 2018;27(5):1309-1323.

56. Nylin S, Janz N. Butterfly host plant range: an example of plasticity as a promoter of speciation? Evolutionary Ecology. 2009;23(1):137-146.

57. Nylin S, Agosta S, Bensch S, Boeger WA, Braga MP, Brooks DR, et al. Embracing colonizations: a new paradigm for species association dynamics. Trends in ecology \& evolution. 2018;33(1):4-14.

58. Olesen JM, Bascompte J, Dupont $\mathrm{YL}$, Jordano P. The modularity of pollination networks. Proceedings of the National Academy of Sciences. 2007;104(50):19891-19896.

59. Patella L, Brooks DR, Boeger WA. Phylogeny and ecology illuminate the evolution of associations under the Stockholm Paradigm: Aglaiogyrodactylus spp. (Platyhelminths, Mongenoidea, Gyrodactylidae) and species of Loricariidae (Actinopterygii, Siluriformes). Vie et Milieu-Life and Environment. 2017;67(2):91-102.

60. Peters RH. The Ecological Implications of Body-Size, Cambridge University Press. 1983.

61. Poulin R. Species richness of parasite assemblages: evolution and patterns. Annual review of Ecology and Systematics. 1997;28(1):341-358.

642 62. Poulin R. Parasites and the neutral theory of biodiversity. Ecography. $643 \quad 2004 ; 27(1): 119-123$.

644 63. Ramalho WP, Machado IF, Vieira LJS. Do flood pulses structure amphibian communities in floodplain environments? Biotropica. 2018;50(2):338-345. 
64. Rezende EL, Albert EM, Fortuna MA, Bascompte J. Compartments in a marine food web associated with phylogeny, body mass, and habitat structure. Ecology Letters. 2009;12(8):779-788.

65. Rigaud T, Perrot-Minnot MJ, Brown MJ. Parasite and host assemblages: embracing the reality will improve our knowledge of parasite transmission and virulence. Proceedings of the Royal Society

B: Biological Sciences. 2010;277(1701):3693-3702.

66. Savage VM, Gillooly JF, Brown JH, West GB, Charnov EL. Effects of body size and temperature on population growth. The American Naturalist. 2004;163(3):429-441.

67. Scordato ES and Kardish MR. Prevalence and beta diversity in avian malaria communities: Host species is a better predictor than geography. Journal of Animal Ecology. 2014;83(6):1387-1397.

68. Stigall AL. When and how do species achieve niche stability over long time scales? Ecography. 2014;37(11):1123-1132.

69. Stigall AL, Bauer JE, Lam AR, Wright DF. Biotic immigration events, speciation, and the accumulation of biodiversity in the fossil record. Global and Planetary Change. 2017;148:242-257.

70.Streicker DG, Turmelle AS, Vonhof MJ, Kuzmin IV, McCracken GF, Rupprecht CE. Host phylogeny constrains cross-species emergence and establishment of rabies virus in bats. Science. 2010;329(5992):676-679.

71. Thomaz SM, Bini LM, Bozelli RL. Floods increase similarity among aquatic habitats in river-floodplain systems. Hydrobiologia. 2007;579(1):1-13. aquáticos e influência dos níveis fluviométricos. In A planície de inundação do 
alto rio Paraná: aspectos físicos, biológicos e socioeconômicos. Maringá: EDUEM. 1997. p. 73-102.

73. Wells K, Gibson DI, Clark NJ. Global patterns in helminth host specificity: phylogenetic and functional diversity of regional host species pools matter. Ecography. 2019;42(3):416-427.

74. Wells K, O'Hara RB, Morand S, Lessard JP, Ribas A. The importance of parasite geography and spillover effects for global patterns of host-parasite associations in two invasive species. Diversity and Distributions. 2015;21(4):477-486.

75. Vermeij GJ, Dudley R. Why are there so few evolutionary transitions between aquatic and terrestrial ecosystems?. Biological Journal of the Linnean Society. 2000;70(4):541-554.

76. Wolfe ND, Dunavan CP, Diamond J. Origins of major human infectious diseases. Nature. 2007;447(7142):279.

77. Woodward G, Ebenman B, Emmerson M, Montoya JM, Olesen JM, Valido A, et al. Body size in ecological networks. Trends in ecology \& evolution. 2005;20(7):402-409.

78.Wright SJ. Density compensation in island avifaunas. Oecologia. $1980 ; 45(3): 385-389$.

79. Zar JH. Biostatistical Analysis, (4th ed.). Prentice-Hall, Upper Saddle River, NJ, USA. 1999. p. 931. 
Figures

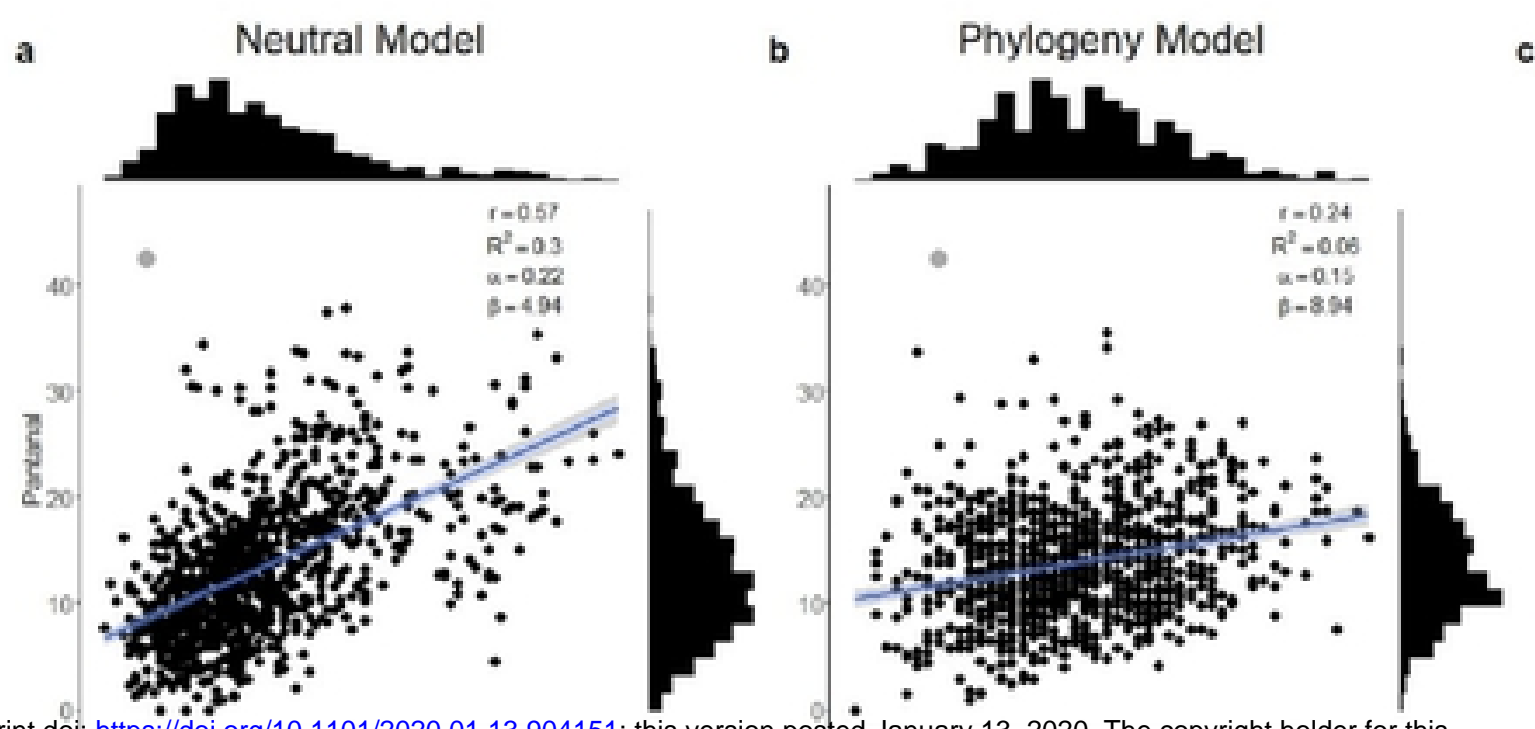

bioRxiv preprint doi: https://doi.org/10.1101/2020.01.13.904151; this version posted January 13,2020. The copyright holder for this
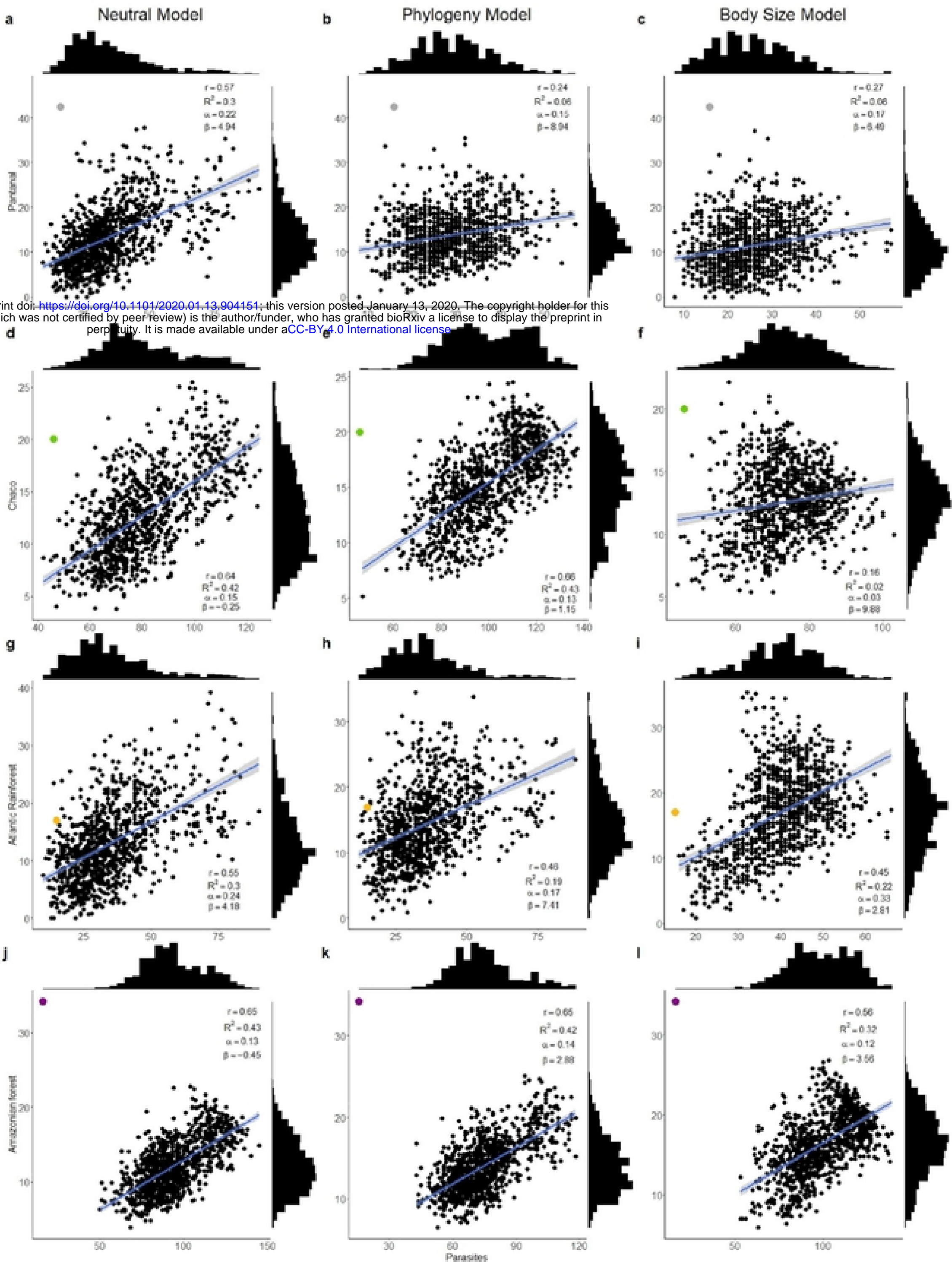

Fig. 1 

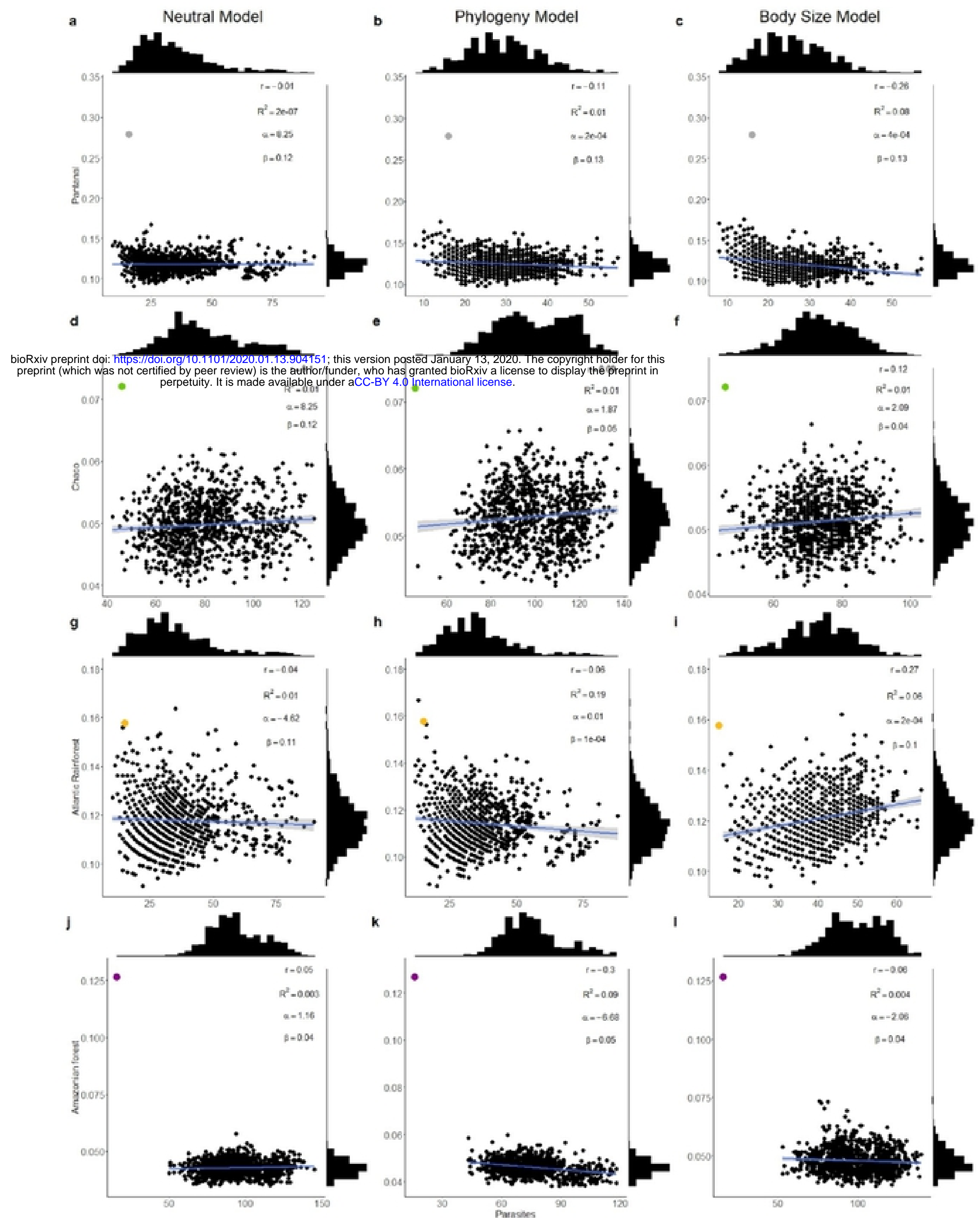

Fig. 2 


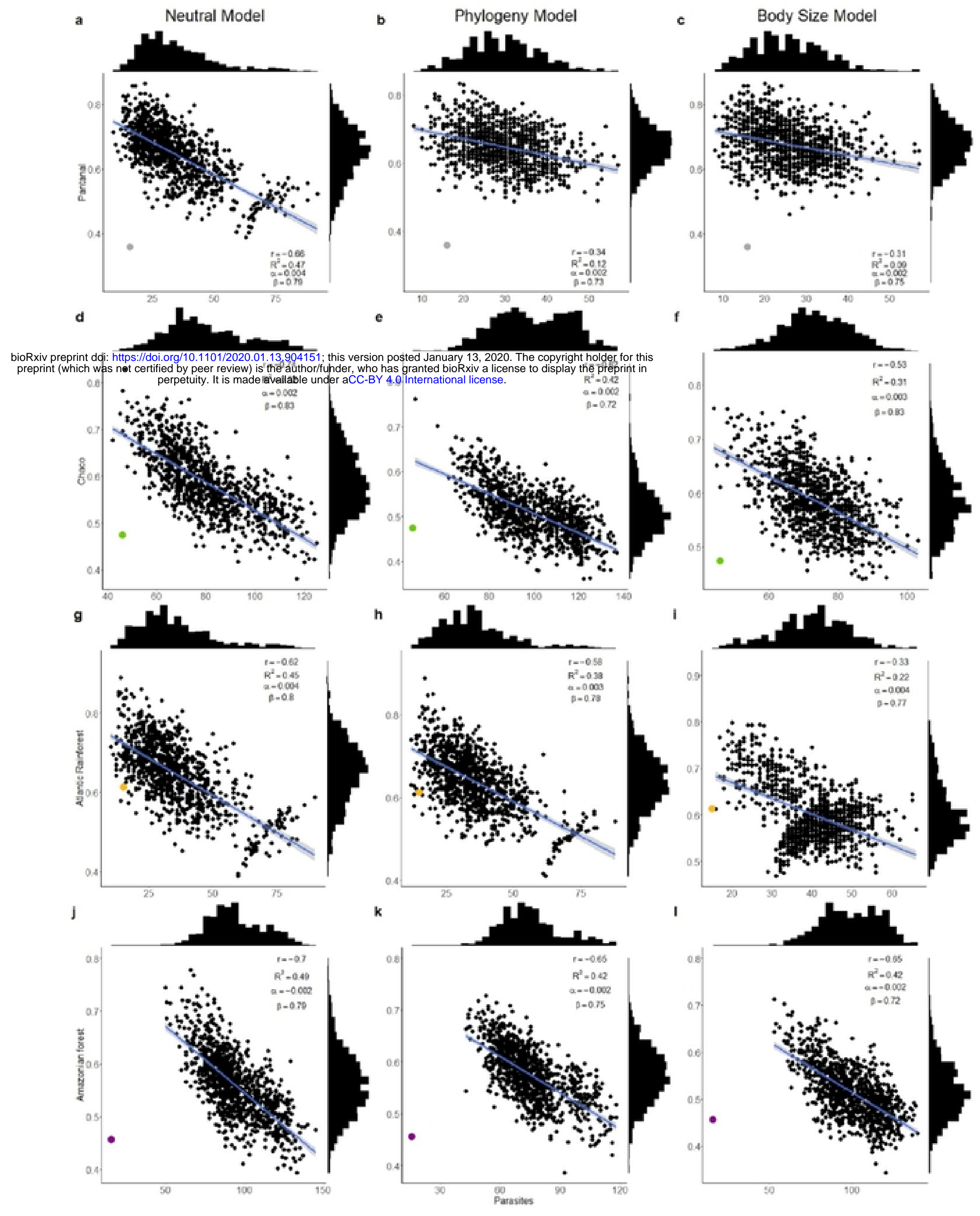

Fig. 3 